\title{
Radioiodine treatment for non-toxic goitre
}

\section{Ulla Feldt-Rasmussen}

Address: Department of Medical Endocrinology, PE 2132, Rigshospitalet, National University Hospital, Blegdamsvej 9, DK-2100 Copenhagen, Denmark

Email: ufeldt@rh.dk

FI000 Medicine Reports 2009, I:70 (doi:I0.34I0/MI-70)

The electronic version of this article is the complete one and can be found at: http://F/000.com/Reports/Medicine/content///70

\begin{abstract}
There is no ideal treatment for benign multinodular goitre. Besides surgery, which is recommended for large goitres or when malignancy cannot be excluded, the non-surgical treatment options are levothyroxine therapy and radioiodine $\left({ }^{|3|} \mid\right)$ therapy. Conventional ${ }^{|3|} \mid$ therapy [without recombinant human thyroid-stimulating hormone (rhTSH)] has been used for more than a decade in symptomatic non-toxic multinodular goitre, and although it does lead to significant thyroid volume reduction, relatively high activities of radioiodine are needed because of a frequent finding of a low thyroid radioiodine uptake. rhTSH, even when used in very small doses in combination with ${ }^{131}$ I therapy, enhances the thyroid volume reduction at lower ${ }^{131} \mid$ activities by doubling the thyroid radioiodine uptake. However, before rhTSH stimulation can be routinely used by clinicians to optimise the ${ }^{|3|} \mid$ therapy in multinodular goitre, aspects of this association, such as the cost-benefit and optimum rhTSH dose and safety, will have to be sufficiently clarified.
\end{abstract}

\section{Introduction and context}

Radioactive iodine has been used extensively for treatment of hyperthyroidism for more than 60 years. As it was noticed that the treatment not only alleviated the hyperthyroid state but also caused goitres to shrink, this therapy was introduced more than 20 years ago as a possible treatment modality in the management of nontoxic goitre [1-6]. The first reports described patients with large multinodular goitres who for other reasons were not eligible for surgery (for example, patients with cardiac or respiratory failure). In one study, it was stated that the use of radioactive iodine therapy constitutes an alternative to surgery in selected patients with large compressive goitres in whom surgery was contraindicated because of age or other medical conditions [7]. Later, treatment was given to patients with diffuse nontoxic goitre, all of whom had serious symptoms but refused surgery [8].

The general treatment modalities for non-toxic goitre are medical treatment with levothyroxine, surgery, and radioactive iodine. Thyroxine treatment for diffuse non-toxic goitre is a well-established modality in some countries, especially in iodine-deficient regions where often the disease affects more than $10 \%$ of the population. A reduction in thyroid volume of $20-30 \%$ within 3 months can be achieved but requires a thyroxine dose that can lead to suppression of serum thyrotropin, tissue thyrotoxicosis, and risk of osteoporosis $[9,10]$. Life-long treatment is necessary, yet most patients will develop nodular thyroid disease, for which thyroxine is much less effective.

Non-toxic multinodular goitres are more prevalent in populations with low or borderline iodine intake. The disease most often starts at a young age with a diffuse enlargement that gradually becomes more nodular with time and with increasing numbers of autonomously functioning nodules $[11,12]$. At the nodular stage, thyroxine therapy is inefficient in reducing thyroid volume since thyrotropin starts to be suppressed by the autonomous nodules, and therefore in most countries surgery has been the only option for therapy $[12,13]$. A fear of increasing the thyroid gland through radiation 
thyroiditis was allayed by a study by Nygaard and colleagues [14], which demonstrated that the inspiratory flow curve was not negatively affected after treatment and that, on the contrary, there was a beneficial effect. Another aspect has been the occurrence of thyroid autoimmunity with a Graves' disease-like reaction after radioiodine therapy [15], in some cases accompanied by thyroid-associated ophthalmopathy [16]. It has not yet been resolved as to whether this is a de novo autoimmunity; instead, it might be existing asymptomatic Graves' disease within a nodular goitre with a transitory deterioration of the autoimmune process due to antigen release after the destructive radiation. Finally, the possibility of a thyroid tumour harboured in a nodular goitre, though rare, must be kept in mind.

The introduction of radioiodine as a treatment modality has advanced the management of these patients on the one hand but has posed some problems on the other hand since many of the populations who were initially low in iodine have now started iodine salt addition programmes, which notoriously lower the uptake of radioiodine. The treatment success therefore is limited and requires much greater amounts of radioiodine to overcome this problem, thus creating a potential environmental problem due to surplus radioiodine excreted in the urine [17].

\section{Recent advances}

The problem of low iodine uptake has recently been overcome by introducing recombinant human thyroidstimulating hormone (rhTSH) as a stimulator before the radioiodine therapy [18-20]. In one of the studies, it was shown that, followed by $1.11 \mathrm{GBq}$, a very low dose of $0.005 \mathrm{mg}$ rhTSH was as safe and effective as $0.1 \mathrm{mg}$ of rhTSH. Both doses increased the efficacy of radioiodine. Adverse events were mild, transient, and readily treatable [19]. Other studies have verified that the uptake was dramatically increased, even by low doses of rhTSH $[21,22]$, and the regional distribution of the uptake can change substantially, thus providing the possibility for efficient shrinkage of previous large cold nodules by even a single low dose of rhTSH [23]. Subsequent studies have investigated issues such as the amount of rhTSH to be used, the timing, and the effect, even in persons with normal thyroid glands [24-26]. As in radioiodine treatment without pre-stimulation, there have been several reports of thyroid enlargements after rhTSH, and some of these enlargements have been very serious [27-29]. However, the general picture shows a safe procedure with a tendency to relieve local tracheal symptoms [30]. An alternative to this treatment has been presented as repeated doses of radioiodine rather than pre-stimulation [31]. When used together, these two modalities may prove to be beneficial in some very difficult cases.

\section{Implications for clinical practice}

Although surgeons still advocate surgery as the treatment of choice in non-toxic goitres $[12,13]$, it seems clear to most clinicians that radioactive iodine therapy is an attractive alternative with few side effects and is easy for the patient as it does not require hospitalisation. The limitation of the therapy of having to use either very high or repeated doses of radioiodine due to many large goitres with low iodine uptake has been overcome by pre-treatment with rhTSH [18-26]. Although this treatment at present is rather expensive, it appears that much smaller doses of the drug have sufficient efficacy, and the price therefore should be adjusted by the production of appropriate ampoule sizes. To further document a more widespread use of rhTSH as a pre-treatment, additional randomised clinical trials comparing doses of rhTSH and comparing radioiodine therapy with surgery in terms of outcome measures such as efficacy of goitre control, thyroid function, health care costs, and health-related quality of life are needed $[32,33]$. Only then can the treatment continue based on solid evidence, which is very likely to change treatment algorithms for non-toxic goitre in the future [34].

\section{Abbreviation}

rhTSH, recombinant human thyroid-stimulating hormone.

\section{Competing interests}

The author has received unrestricted research grants from Genzyme (Cambridge, MA, USA) and has served on one of the advisory boards of the same company.

\section{References}

I. Bell PR, Hegedüs L, Hansen JM: Radioactive iodine for thyrotoxicosis. Lancet 1986, 2:339-40.

2. Hegedüs L, Hansen BM, Knudsen N, Hansen JM: Reduction of size of thyroid with radioactive iodine in multinodular non-toxic goitre. BMJ 1988, 297:661-2.

3. Nygaard B, Hegedüs L, Gervil M, Hjalgrim H, Soe-Jensen P, Hansen JM: Radioiodine treatment of multinodular non-toxic goitre. $B M$ J 1993, 307:828-32.

4. Huysmans DA, Hermus AR, Corstens FH, Barentsz JO, Kloppenborg PW: Large, compressive goiters treated with radioiodine. Ann Intern Med 1994, I 2 I:757-62.

5. Wesche MF, Tiel-Van Buul MM, Smits NJ, Wiersinga WM: Reduction in goiter size by ${ }^{131} \mid$ therapy in patients with non-toxic multinodular goiter. Eur J Endocrinol 1995, 132:86-7.

6. Le Moli R, Wesche MF, Tiel-Van Buul MM, Wiersinga WM: Determinants of longterm outcome of radioiodine therapy of sporadic non-toxic goitre. Clin Endocrinol (Oxf) 1999, 50:783-9.

7. Verelst J, Bonnyns M, Glinoer D: Radioiodine therapy in voluminous multinodular non-toxic goitre. Acta Endocrinol (Copenh) 1990, 122:417-21. 
8. Hegedüs L, Bennedbæk FN: Radioiodine for non-toxic diffuse goitre. Lancet 1997, 350:409-10.

9. Hansen JM, Kampmann J, Madsen SN, Skovsted L, Solgaard S, Grytter C, Grøntvedt T, Rasmussen SN: I-Thyroxine treatment of diffuse non-toxic goitre evaluated by ultrasonic determination of thyroid volume. Clin Endocrinol (Oxf) 1979, 10: I-6.

10. Wesche MF, Tiel-Van Buul MM, Lips P, Smits NJ, Wiersinga WM: $A$ randomized trial comparing levothyroxine with radioactive iodine in the treatment of sporadic nontoxic goiter. J Clin Endocrinol Metab 200I, 86:998-1005.

II. Berghout A, Wiersinga WM, Smits NJ, Touber JL: Interrelationships between age, thyroid volume, thyroid nodularity, and thyroid function in patients with sporadic nontoxic goiter. Am J Med 1990, 89:602-8.

I2. Hegedüs L, Bonnema SJ, Bennedbæk FN: Management of simple nodular goiter. Endocr Rev 2003, 24:102-32.

13. Bhagat MC, Dhaliwal SS, Bonnema SJ, Hegedüs L, Walsh JP: Differences between endocrine surgeons and endocrinologists in the management of non-toxic multinodular goitre. $\mathrm{Br} J$ Surg 2003, 90:1103-12.

14. Nygaard B, Soes-Petersen U, Hoilund-Carlsen PF, Veje A, Holst PE, Vestergaard A, Solling K: Improvement of upper airway obstruction after $\left.{ }^{3}\right|_{1}$-treatment of multinodular nontoxic goiter evaluated by flow volume loop curves. J Endocrinol Invest 1996, 19:71-5.

15. Nygaard B, Knudsen JH, Hegedüs L, Scient AV, Hansen JE: Thyrotropin receptor antibodies and Graves' disease, a side-effect of ${ }^{131} 1$ treatment in patients with nontoxic goiter. J Clin Endocrinol Metab 1997, 82:2926-30.

16. Nygaard B, Metcalfe RA, Phipps J, Weetman AP, Hegedüs L: Graves' disease and thyroid associated ophthalmopathy triggered by ${ }_{131}$ I treatment of non-toxic goiter. J Endocrinol Invest 1999, 22:481-5.

17. Huysmans DA, Buijs WC, van de Ven MT, van den Broek WJ, Kloppenborg PW, Hermus AR, Corstens FH: Dosimetry and risk estimates of radioiodine therapy for large, multinodular goiters. J Nucl Med 1996, 37:2072-9.

18. Nielsen VE, Bonnema SJ, Hegedüs L: Effects of $\mathbf{0 . 9} \mathbf{~ m g ~ r e c o m b i - ~}$ nant human thyrotropin on thyroid size and function in normal subjects: a randomized, double-blind, cross-over trial. J Clin Endocrinol Metab 2004, 89:2242-7.

19. Huysmans DA, Nieuwlaat WA, Erdtsieck RJ, Schellekens AP, Bus JW, Bravenboer B, Hermus AR: Administration of a single low dose of recombinant human thyrotropin significantly enhances thyroid radioiodide uptake in nontoxic nodular goiter. J Clin Endocrinol Metab 2000, 85:3592-6.

20. Silva MN, Rubió IG, Romão R, Gebrin EM, Buchpiguel C, Tomimori E, Camargo R, Cardia MS, Medeiros-Neto G: Administration of a single dose of recombinant human thyrotrophin enhances the efficacy of radioiodine treatment of large compressive multinodular goitres. Clin Endocrinol (Oxf) 2004, 60:300-8.

21. Cubas ER, Paz-Filho GJ, Olandoski M, Goedert CA, Woellner LC, Carvalho GA, Graf H: Recombinant human TSH increases the efficacy of a fixed activity of radioiodine for treatment of multinodular goitre. Int J Clin Pract 2009, 63:583-90.
22. Bonnema SJ, Nielsen VE, Hegedüs L: Radioiodine therapy in nontoxic multinodular goitre. The possibility of effect-amplification with recombinant human TSH (rhTSH). Acta Oncol 2006, 45: $1051-8$.

23. Nieuwlaat WA, Hermus AR, Sivro-Prndelj F, Corstens FH, Huysmans DA: Pretreatment with recombinant human TSH changes the regional distribution of radioiodine on thyroid scintigrams of nodular goiters. J Clin Endocrinol Metab 200I, 86:5330-6.

24. Nielsen VE, Bonnema SJ, Hegedüs L: The effects of recombinant human thyrotropin, in normal subjects and patients with goitre. Clin Endocrinol (Oxf) 2004, 6 I:655-63.

25. Nieuwlaat WA, Hermus AR, Ross HA, Buijs WC, Edelbroek MA, Bus JW, Corstens FH, Huysmans DA: Dosimetry of radioiodine therapy in patients with nodular goiter after pretreatment with a single, low dose of recombinant human thyroidstimulating hormone. J Nucl Med 2004, 45:626-33.

26. Torres MS, Ramirez L, Simkin PH, Braverman LE, Emerson $\mathrm{CH}$ : Effect of various doses of recombinant human thyrotropin on the thyroid radioactive iodine uptake and serum levels of thyroid hormones and thyroglobulin in normal subjects. J Clin Endocrinol Metab 200I, 86: I660-4.

27. Braga M, Ringel MD, Cooper DS: Sudden enlargement of local recurrent thyroid tumor after recombinant human TSH administration. J Clin Endocrinol Metab 200 I, 86:5I48-5I.

28. Goffman T, loffe V, Tuttle M, Bowers JT, Mason ME: Near lethal respiratory failure after recombinant human thyroid stimulating hormone use in a patient with metastatic thyroid carcinoma. Thyroid 2003, 13:827-30.

29. Nielsen VE, Bonnema SJ, Hegedüs L: Transient goiter enlargement after administration of $0.3 \mathrm{mg}$ recombinant human thyrotropin in patients with benign nontoxic nodular goiter: a randomized, double-blind, cross-over trial. J Clin Endocrinol Metab 2006, 91:1317-22.

30. Bonnema SJ, Nielsen VE, Boel-Jørgensen H, Grupe P, Andersen PB, Bastholt L, Hegedüs L: Recombinant human thyrotropinstimulated radioiodine therapy of large nodular goiters facilitates tracheal decompression and improves inspiration. J Clin Endocrinol Metab 2008, 93:398I-4.

31. Baczyk M, Pisarek M, Czepczynski R, Ziemnicka K, Gryczynska M, Pietz L, Sowinski J: Therapy of large multinodular goitre using repeated doses of radioiodine. Nud Med Commun 2009, 30: 226-31.

32. Watt T, Groenvold M, Rasmussen AK, Bonnema SJ, Hegedüs L, Bjorner JB, Feldt-Rasmussen U: Quality of life in patients with benign thyroid disorders. A review. Eur J Endocrinol 2006, 154:501-10.

33. Watt $T$, Rasmussen AK, Groenvold M, Bjorner JB, Watt SH, Bonnema SJ, Hegedüs L, Feldt-Rasmussen U: Improving a newly developed patient-reported outcome for thyroid patients, using cognitive interviewing. Qual Life Res 2008, I7:1009-I7.

34. Fast S, Nielsen VE, Bonnema SJ, Hegedüs L: Time to reconsider nonsurgical therapy of benign non-toxic multinodular goitre: focus on recombinant human $\mathrm{TSH}$ augmented radioiodine therapy. Eur J Endocrinol 2009, 160:517-28. 